\title{
PROJECT FINAL TECHNICAL REPORT
}

\author{
MOLECULAR APPROACHES FOR IN SITU IDENTIFCIATION OF NITRATE \\ UTILIZATION BY MARINE BACTERIA AND PHYTOPLANKTON
}

DOE A ward Number: $\quad$ DE-FG02-98ER62531

SkIO Report: DOE/ER/62537-038-1

PI: $\quad$ Marc E. Frischer (SkIO)

Skidaway Institute of Oceanography

100 cean Science Circle

Savannah, GA 31411

marc.frischer@ skio.uga.edu

(912) 598-2308 (office)

(912) $598-2310$ (fax)

Co-PI's: $\quad$ Peter G. V erity (Skidaway Institute of Oceanography)

M atthew R. Gilligan (Savannah State U niversity)

Deborah A. Bronk (University of Georgia)

J onathan P. Zehr (Renssel aer Polytechnic Institute, 1998 - 2001)

M elissa G. B ooth (Roanoke College, 2004 - 2007)

Revised report submitted September 13, 2013 


\section{Executive Summary}

In response to the US Department of Energy's solicitation for the B iotechnology Investigations - Ocean M argins Program we were awarded three separate projects spanning the period from N ovember 1997 through N ovember 2006. The project was further extended to N ovember 2007 with a no cost extension.

Traditionally, the importance of inorganic nitrogen $(\mathrm{N})$ for the nutrition and growth of marine phytoplankton has been recognized, while inorganic $\mathrm{N}$ utilization by bacteria has received less attention. Likewise, organic $\mathrm{N}$ has been thought to be important for heterotrophic organisms but not for phytoplankton. However, accumulating evidence suggests that bacteria compete with phytoplankton for nitrate $\left(\mathrm{NO}_{3}{ }^{-}\right)$and other $\mathrm{N}$ species. The consequences of this competition may have a profound effect on the flux of $\mathrm{N}$, and therefore carbon $(\mathrm{C})$, in ocean margins. Because it has been difficult to differentiate between $\mathrm{N}$ uptake by heterotrophic bacterioplankton versus autotrophic phytoplankton, the processes that control $\mathrm{N}$ utilization, and the consequences of these competitive interactions, have traditionally been difficult to study. Significant bacterial utilization of DIN may have a profound effect on the flux of $\mathrm{N}$ and $\mathrm{C}$ in the water column because sinks for dissolved $\mathrm{N}$ that do not incorporate inorganic $\mathrm{C}$ represent mechanisms that reduce the atmospheric $\mathrm{CO}_{2}$ drawdown via the "biological pump" and limit the flux of POC from the euphotic zone.

The overall scientific objective of this project was to develop a novel set of molecular (genetic)-enabled tools that could be utilized to estimate key ocean margin biogeochemical rates that link the carbon and nitrogen cycles.

It was also a primary objective of this project to develop a meaningful and sustainable relationship between the Skidaway Institute of O ceanography (SkIO) and Savannah State University (SSU) with the long-term goal of enhancing the diversity of the future STEM workforce, particularly the representation of A frican A mericans in the M arine Sciences and Biotechnology. SSU is a Historically B lack University with programs in M arine Sciences, Environmental Sciences and Biotechnology. Specific partnership objectives during this project included enhancing curricular offerings in the marine science in both the undergraduate and graduate programs at SSU, the provision of undergraduate research internship opportunities for SSU students, the institutionalization of the SSU/SkIO collaborative responsibility for the new $M$ asters of $M$ arine Science program at SSU and the acquisition of additional research/education funds from state and federal sources. Significant efforts to recruit, retain, and support graduate students within the scientific context of this study were al so made.

During the first phase of this project (1997 - 2000) we pursued the hypothesis that the assimilatory nitrate reductase genes from autotrophic cyanobacteria and heterotrophic bacteria have conserved regions with sufficient group-specific divergence to facilitate a molecular, PCR-based approach to identifying the abundance, distribution, and activity of particular nitrate assimilating organisms and groups of organisms. A ctivities involved developing global sequence databases of nasA (heterotrophic bacteria) and nar B (cyanobacteria and eukaryote) gene diversity and developing PCR-based techniques to explore the expression of these genes in ocean margin environments. $V$ alidation of this approach was accomplished using laboratory 
and field incubation studies where both molecular and more classical ${ }^{15} \mathrm{~N}$ radiotracer studies were performed simultaneously. In support of the partnership objectives a significant undergraduate research internship program was established between SkIO and SSU and several courses were developed and offered at SSU by BI-OM P investigators.

During the second project phase (2001 - 2003) we focused on the development of nasA groupspecific primer sets suitable for use in qPCR and qRT-PCR assays. These new assays were utilized in concert with several laboratory and field studies that allowed levels of gene abundance and expression to be directly compared to estimated $\mathrm{N}$-uptake rates by bacteria and phytoplankton. The results of these studies supported the overall hypothesis that real time molecular measurements of nasA gene abundance and expression can be used as a proxy for estimated bacterial $\mathrm{NO}_{3}$ uptake rates. In support of the project partnership goals, the undergraduate research intership program was continued, curriculum development was continued and sustained and a proposal was developed and submitted to the U niversity System of Georgia for a new M asters program in M arine Sciences at SSU.

During the third project phase (2004 - 2007) research efforts focused on identifying ecologically relevant properties of nasA gene expression in representative nasA-containing bacteria representative of the genetic diversity of this gene. The results of these studies indicated that phylogenetic variation in the nasA gene sequence is not correlated with overall $\mathrm{NO}_{3}$ uptake rates and thus it is not possible to extrapolate from diversity studies the potential for bacterial $\mathrm{NO}_{3}$ assimilation. Efforts also focused on the conceptual integration of bacterial $\mathrm{NO}_{3}-$ utilization patterns into 0 cean Carbon cycling M odels (OCM s). The results of these preliminary modeling studies confirmed the hypothesis that bacterial competition with phytoplankton for $\mathrm{NO}_{3}$ may have profound impacts on global carbon cycling. In support of research/education partnership goals several significant breakthroughs occurred. The SSU $M$ asters program in M arine Sciences was approved by the U niversity of Georgia System and the program was initiated in 2004. The first class began to graduate in 2007. A dditional funding to support the SkIO/SSU partnership was acquired from the US National Science Foundation and the US D epartment of Education. A lthough no new state funds were approved, the success at a national level of the SSU M asters Program precipitated the administration of SSU to designate the program as its flagship graduate program. 


\section{Science Objectives}

The overall scientific objective of this project was to develop a novel set of molecular (genetic)-enabled tools that could be utilized to estimate key ocean margin biogeochemical rates that link the carbon and nitrogen cycles. Specific science objectives during the final project period focused largely on I) the completion of analysis and synthesis of the efforts of the previous two project years, II) the initiation of experimental studies utilizing bacterial isolates with genetically distinct sequences of nasA genes to determine the ecologically significance, if any, of genetic diversity of nasA containing bacterial communities, and III) investigations of the diversity of ureC genes associated with coastal and estuarine bacterial communities. A fourth objective was the continuation of the development of molecular (nucleic acid) and flow cytometry-based technology for field (ocean) application.

\section{Partnership O bjectives}

Specific partnership objectives during this project included enhancing curricular offerings in the marine science in both the undergraduate and graduate programs at SSU, the provision of undergraduate research internship opportunities for SSU students, the institutionalization of the SSU/SkIO collaborative responsibility for the new masters of marine science program at SSU, and the acquisition of additional research/education funds from state and federal sources. Significant efforts to recruit, retain, and support graduate students within the scientific context of this study were also made.

\section{Summary of Research 0 bjectives, Findings and Implications.}

\section{Diversity and E cological Significance of the nasA gene (Phase I - 1997-2000).}

During the first phase of this project we pursued the hypothesis that the assimilatory nitrate reductase genes from autotrophic cyanobacteria and heterotrophic bacteria have conserved regions with sufficient group-specific divergence to facilitate a molecular, PCR-based approach to identifying the abundance, distribution, and activity of particular nitrate assimilating organisms and groups of organisms. A ctivities involved developing global sequence databases of nasA (heterotrophic bacteria) and nar B (cyanobacteria and eukaryote) gene diversity and developing PCR-based techniques to explore the expression of these genes in ocean margin environments. V alidation of this approach was accomplished using laboratory and field incubation studies where both molecular and more classical ${ }^{15} \mathrm{~N}$ radiotracer studies were performed simultaneously.

During this project phase we expanded our knowledge of nasA gene diversity from one sequence to over 500 (Figure 1). PCR primer sets were developed that enabled the specific amplification of an $\sim 800$ bp fragment of the heterotrophic bacteria assimilatory nitrate reductase gene (nasA) that was uniquely differentiated from the cyanobacteria and eukaryotic assimilatory nitrate reductase gene (narB). 


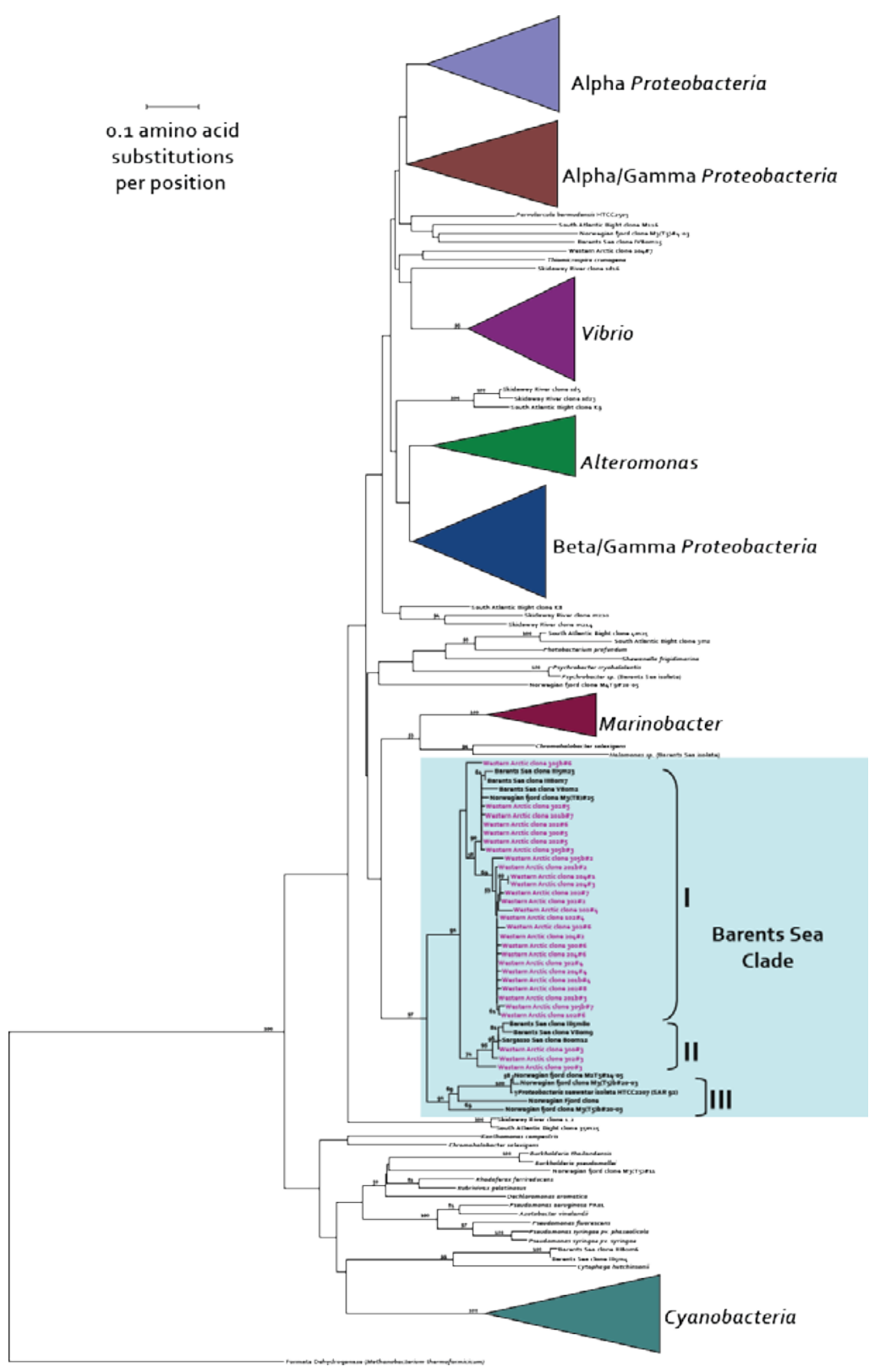

Figure 1. Global phylogenetic diversity of the bacterial assimilatory nitrate reductase gene (nasA). Phylogenetic tree constructed from over 500 nasA sequences collected from ocean margin regions around world. Phylogenetic reconstructions based on inferred amino acid sequences. Globally, the most commonly retrieved nasA sequences belong to the Barents Sea Clade for which we have no cultured representatives.

These studies indicate that the ability of heterotrophic bacteria to utilize nitrate is ubiquitous in the world's ocean margins (Figure 2). Thus, there exists the potential for direct competition between autotrophic phytoplankton and heterotrophic bacteria for nitrate. B ecause nitrate limits net primary production in most oceanic regions, the competition between heterotrophs and autotrophs for nitrate has profound implications for global carbon cycling. 


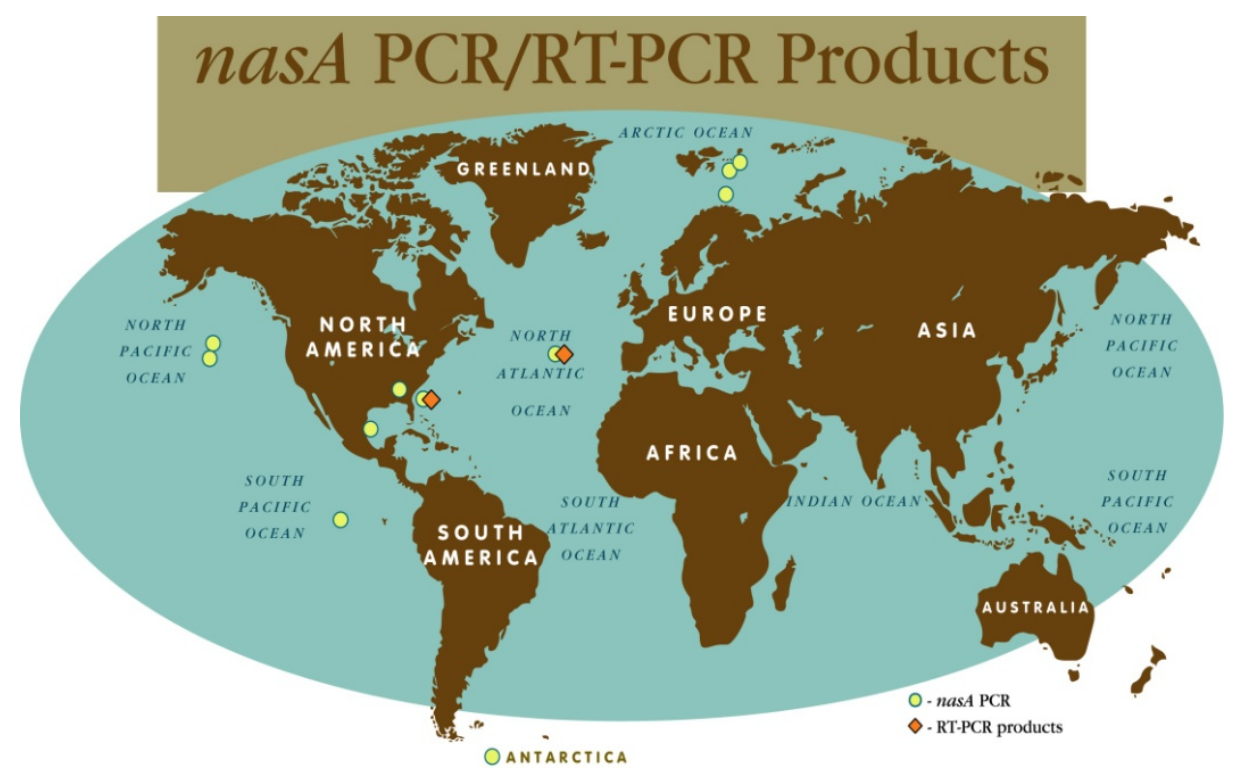

Figure 2. Global distribution of nasA gene and gene transcripts in the world's oceans. nasA genes and gene transcripts were detected in all locations where they were investigated.

\section{Merging M olecular and Biogeochemical Measurements (Phase II - 2001-2003).}

During the second project phase we focused on the development of nasA group-specific primer sets suitable for use in qPCR and qRT-PCR assays. These new assays were utilized in concert with several laboratory and field studies that allowed levels of gene abundance and expression to be directly compared to estimated $\mathrm{N}$-uptake rates by bacteria and phytoplankton.

Group specific primer sets for three major clades of nasA containing bacteria were designed, developed, validated and utilized in several sets of laboratory and field studies. Culture-based studies were conducted to investigate the regulation of nasA gene expression. In these studies it was observed that some groups of nasA-containing bacteria could regulate gene expression in response to the availability of more reduced species of $\mathrm{N}$ while others constitutively expressed the nasA gene (Figure 3). Field studies in subtropical estuaries, the South A tlantic Bight, the mid-A tlantic Bight, the N orth A tlantic Ocean and the Barents Sea reveal ed a high correlation between nasA gene abundance, expression and $\mathrm{NO}_{3}{ }^{-}$uptake rates estimated from ${ }^{15} \mathrm{~N}$ tracer studies (Figure 4). 


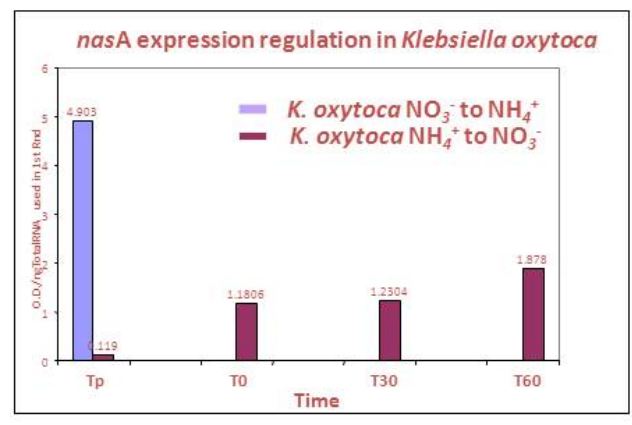

nasA expression regulation in Vibrio diazotrophicus
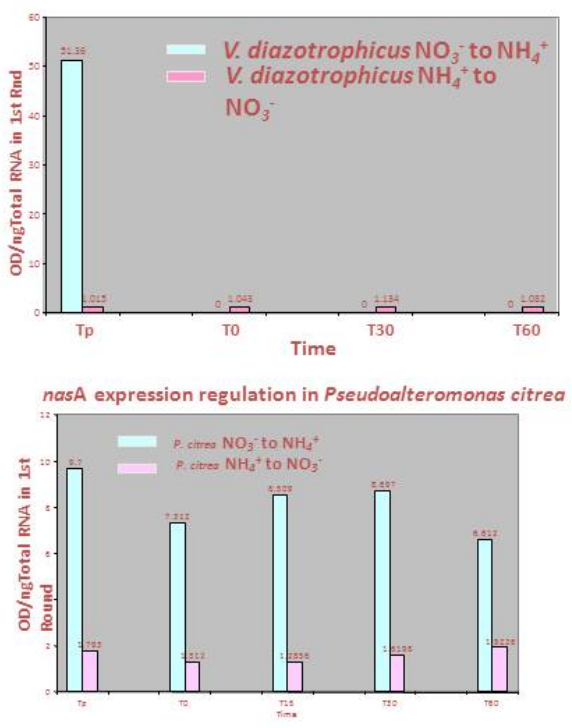

Figure 3. Regulation of the nasA gene in 3 different nasA containing bacteria. Cultures were either grown in media containing $\mathrm{N}_{3}$ or $\mathrm{NH}_{4}$ and then washed and switched to media containing the alternate $\mathrm{N}$ source. K. oxytoca exhibited a classical regulation pattern with the nasA gene expressed in the presence of $\mathrm{NO}_{3}$ and repressed when $\mathrm{NH}_{4}$ was present. Alternatively, $\mathrm{V}$. diazotrophicus expressed the nasA gene when $\mathrm{NO}_{3}$ was present but removal of $\mathrm{NH}_{4}$ did not result in activated expression repressed cultures. Alternatively, nasA was constitutively expressed in $\mathrm{P}$. citrea

These studies confirm the ubiquity of heterotrophic bacteria with the ability to utilize $\mathrm{NO}_{3}^{-}$as a primary source of $\mathrm{N}$ and support the hypothesis that biogeochemical rates of $\mathrm{NO}_{3}^{-}$ utilization by heterotrophic bacteria can be estimated based

on molecular measurements of nasA gene expression and gene abundance. Further, these studies suggest that in especially in regions where bacterial are not carbon limited, nitrate uptake can be significant. However, studies conducted in large $\left(11 \mathrm{~m}^{3}\right)$ mesocosms in a Norwegian fjord that simulated a spring phytoplankton bloom, indicated that phytoplankton were al ways able to outcompete heterotrophic bacteria for $\mathrm{NO}_{3}$.

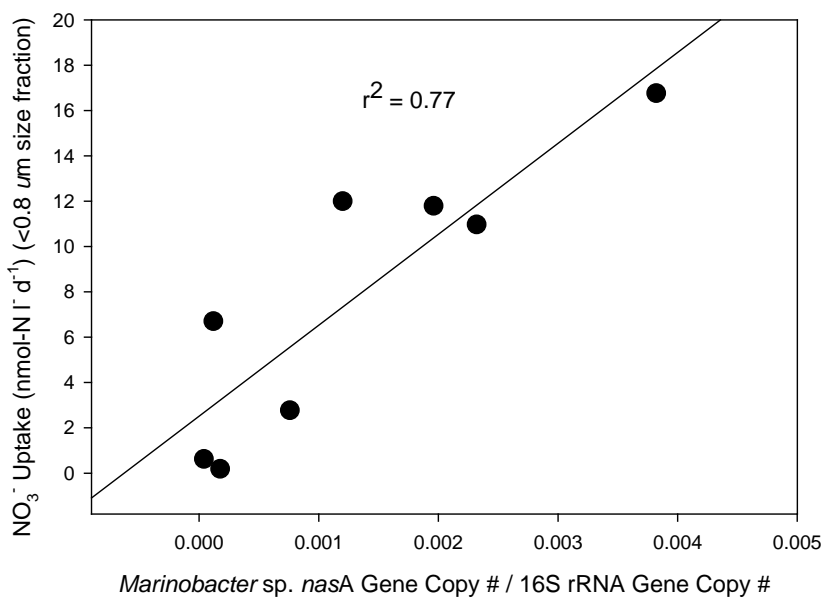

Figure 4. Relationship between $\mathrm{NO}_{3}$ uptake and normalized nasA gene abundance in bacterial communities from the South A tlantic Bight. 


\section{E cological Significance of nasA G ene Diversity and Incorporation in Basin Scale O cean Carbon Cycle M odels (Phase III - 2004-2007).}

During the final project phase efforts focused on identifying ecologically relevant properties of nasA gene expression in representative nasA-containing bacteria representative of the genetic diversity of this gene. Efforts al so focused on the conceptual integration of bacterial $\mathrm{NO}_{3}{ }^{-}$ utilization patterns into Ocean Carbon cycling M odels (OCM s).

To explore the ecological significance of nasA gene diversity, laboratory-based studies utilizing axenic cultures of nasA containing bacteria examined growth-rate, yields and nasA gene expression under a variety of growth conditions. These studies revealed considerable variability associated with these parameters. However, this variability seemed to be independent of the variability of the nasA gene sequence. Disappointedly, this finding suggests that it will be difficult to predict the response of bacterial nitrate utilization based on the composition of nasA assemblage of a bacterial community alone.

To extrapolate the conceptual findings of this study to the global scale, we integrated the ability of heterotrophic bacteria to compete with phytoplankton for nitrate. Although insufficient data on many rate processes made it difficult to realistically implement the bacterial/phytoplankton competitive dynamic, in silico experiments suggest profound implications of such a competition. For example, shunting $10 \%$ of available nitrate from phytoplankton to heterotrophic bacteria resulted in significant reduction in the ability of the ocean to drawdown $\mathrm{CO}_{2}$ and export carbon out of the mixed layer (Figure 5).


Figure 5. M odel outputs of $\mathrm{pCO}_{2}$ and $\mathrm{POC}$ flux when bacteria are not allowed to utilize $\mathrm{NO}_{3}$ for growth ( $\mathrm{A} \& \mathrm{C}$ ) and w2hen $10 \%$ of $\mathrm{NO}_{3}$ is shunted to stimulate bacterial growth $(B \& D)$. Simulations were run using a Basin Scale OCM model for the Southern Ocean (after W alsh et al 2001). 
This same model treatment also suggested that production at the top of the food web could be significantly impacted. However, it should be noted that significantly more information and experimental studies are required to confirm these findings.

\section{Summary of Partnership Activities}

A $n$ integral priority of the DOE BI-OM P program was to foster research/education-based partnerships between research institutions and minority serving institutions. A ccordingly, this program involved a substantial partnership between the Skidaway Institute of Oceanography and Savannah State U niversity (SSU). Savannah State U niversity is a Historically Black University (HBCU) with both undergraduate and graduate programs in $\mathrm{M}$ arine Sciences. The $\mathrm{BI}-\mathrm{OM}$ P program supported these programs and contributed to the development of a new $M$ asters program in M arine Sciences at SSU. The other research partner institutions including the University of Georgia (UGA), Renssel aer Polytechnic Institute (RPI) (project phase I) and the V irginia Institute of M arine Sciences (VIM S) (Phase II \& III) supported this partnership. A dditionally, during the final phase of the project Dr. M elissa B ooth who had been a postdoctoral researcher with a joint appointment at SkIO and SSU accepted a faculty position at R oanoke College (RC). A t Roanoke, Dr. B ooth continued both her research and education engagement in the project during the final 3 years of the project.

The partnership with SSU involved three primary components: 1) Undergraduate and graduate support and mentorship, 2) Curricular enhancement and 3) Development of a joint graduate program (masters level) in marine science at SSU. The highlights and accomplishments of these project components are summarized below.

\section{Student Support and M entorship}

Over the course of this BI-OM P project 24 undergraduate students were either directly or indirectly were supported and mentored through the BI-OM P program. The majority of these students were A frican A merican and have, since the completion of the program, matriculated from SSU and pursued careers in STEM areas. Each student research internship was awarded on a competitive basis. A ward competitions considered academic achievement and letters of recommendation but awards were heavily weighted to students who expressed and could demonstrate real motivation to be involved. These less tangible attributes were eval uated based on an essay prepared by the student, letters or recommendation and mentor evaluations after a day-long orientation program held in association with each round of application. A critical component of the research mentorship program involved a careful mentor/student matching process.

In addition to the undergraduate research opportunities afforded by this project, this program supported $6 \mathrm{M}$ asters students, 4 D octoral students and 2 Postdoctoral fellows. 


\section{C urriculum Enhancement at SSU}

A primary goal of this BI OM P project was the enhancement of the curriculum in M arine Sciences at Savannah State U niversity. To enhance the SSU program in M arine Sciences BIOM P investigators at SkIO developed and taught courses at SSU. Over the course of the BIOM P program 4 courses were developed and offered at SSU by BI-OM P investigators. Courses included: Coastal Oceanography (M SCI 5202), M arine M icrobial Ecology ( $\mathrm{M} \mathrm{SCI}$ 7801), A nalytical Techniques in Seawater, Soils, and Sediment (M SCI 6550), and Current Issues in Oceanography (M SCI 4501/6501). In addition, specialized courses were offered in M olecular Ecology and B ioinformatics as Directed Research courses to support the research training of graduate students directly involved in BI-OM P research.

Coastal O ceanography ( $\mathrm{M} \mathrm{SCl} 5202$ ) is a 4 credit team-taught introductory graduate course that serves as part of the core graduate curriculum of the joint SSU-SkIO masters program in $M$ arine Science at Savannah State U niversity. This program was developed jointly by SSU and SkIO faculty and began formally in 2004 with approval from the USG Board of Regents. In addition to DOE support, funding from NSF through the CIRE (Collaboration to Integrate Research and Education) program, and the Department of Education Title III (Part F) program to strengthen minority-serving institutions. No funding for this initiative was provided by the University System of Georgia. M SCI 5202 was first taught by SkIO faculty in Fall 2004, every following spring thereafter until 2009, and again in the Fall of 2010 - 2012. Class sizes have ranged from 2-13 students per semester. V erity was the course lead from 2004-2009 and F rischer assumed leadership from 2010 until the present. The current structure of the course involves 4 modules taught by Blanton, Sanders or B randes, A lexander, and Frischer with various guest lectures by other SkIO faculty throughout the semester. M ost SkIO faculty have contributed at some level to this course over its history.

$\mathrm{M}$ arine $\mathrm{M}$ icrobial Ecology ( $\mathrm{M} \mathrm{SCl} 7802$ ) is a senior graduate level 3 credit seminar format course. The course has been offered twice by Frischer, first in the Fall of 2003 ( 6 students) and again in the Fall of 2005 (8 students). This course served specifically to support the BI-OM P research goals and thereby, in addition to enhancing curricular offerings at SSU enhanced $\mathrm{BI}$ OM P- specific research activities.

A nalytical Techniques in Seawater, Soils, and Sediment (M SCI 6550). This is a senior level 3 credit methods course. The course has been offered twice by K. M aruya. First in the Fall of 2004 (8 students) and again in the Fall of 2005 (3 students).

Current Issues in Oceanography (M SCI 4501/6501). This was a capstone undergraduate course cross listed as a graduate course. The course was conceived by Frischer and $V$ erity as a component of the DOE BI-OM P program and developed by project postdocs M elissa B ooth and J ennifer B rofft (Bailey). The course was offered during the Fall semesters 1999-2006 when the BI-OM P program concluded. The course fulfilled one of the specific objectives of the $\mathrm{BI}-\mathrm{OM}$ P program, and resulted in one publication (Gilligan et al $2007 \mathrm{~J} \mathrm{ournal}$ of Geosciences Education 55: 531-540). 
In addition to new BI-OM P sponsored courses at SSU, during the third project phase Dr. B ooth developed and offered an undergraduate course in environmental microbiology which emphases marine systems and the incorporation of molecular ecology.

\section{Collaborative SSU/SkIO M asters Program}

A long term objective of this BI OM P program was to support the establishment of a collaboratively administrated and taught $M$ asters degree program in $M$ arine Sciences at SSU. The establishment of this program is viewed as the primary mechanism that will allow the continuation of the collaborative relationship between SSU and SkIO beyond specific DOE funding. During the second phase of this project a proposal for the new degree program was devel oped and received approval from the U niversity System of Georgia. The program accepted its first students in the Fall of 2002 and began graduating students in 2004. The program is having a significant impact on diversifying the marine sciences workforce. For example, between 2004 - 2007 a total of 35 M S degrees were granted. On a national basis, $33 \%$ of all masters degrees in marine sciences earned by A frican A mericans were by students in the SSU/SkIO program. SSU M S graduates al so have been retained at a relatively high rate. Since its inception $20 \%$ of SSU M S graduates have continued in PhD programs and $47 \%$ of the graduates are employed in STEM areas. 


\section{OUTPUT}

\section{Publications}

1. Bradley, P.B., D.A. Bronk, M .E. Frischer, J.E. Brofft, J.H. B raxton, M .G. B ooth, M .P. Sanderson, and L.J. K erkhof. (2010). Inorganic and organic nitrogen uptake by phytoplankton and heterotrophic bacteria in the stratified M id-A tlantic Bight. Estuarine, Coastal and Shelf Science. 88: 429-441.

2. B radley, P.B., M.P. Sanderson, J.C. N ejstgaard, A.F. Sazhin, M .E. Frischer, L.M . K illbergThoreson, P.G. Verity, L. Campbell, and D.A. B ronk. (2010). Nitrogen uptake by phytoplankton and bacteria during an induced Phaeocystis pouchetii bloom, measured using size fractionation and flow cytometeric sorting. Aquatic M icrobial Ecology. 61: 89-104.

3. Bradley, P. B., M . L omas, and D. A . B ronk. (2010). Inorganic and organic nitrogen use by phytoplankton along Chesapeake Bay measured using a flow cytometric approach. Estuaries and Coasts. 33: 971-984.

4. Sanderson, M.P., D.A. Bronk, J.C. N ejstgaard, P.G. V erity, A.F. Sazhin, and M .E. Frischer. (2008). Phytoplankton and bacterial uptake of inorganic and organic nitrogen during an induced bloom of Phaeocystis pouchetii. A quatic M icrobial E cology. 51: 153-168.

5. Gilligan, M .R., P.G. V erity, C.B. Cook, S.B. Cook, M.G. B ooth, and M .E. Frischer. (2007). Building a diverse and innovative ocean workforce through collaboration and partnerships that integrate research and education: HBCUs and marine laboratories. J ournal of G eosciences Education. 55: 531-540.

6. Jacobsen, A ., A . Larsen, J. M artinez-M artinez, M .E. Frischer, P.G. V erity. (2007). Susceptibility of colonies and colonial cells of Phaeocystis pouchetii (Haptophyta) to viral infection. Aquatic M icrobial Ecology. 48: 105-112.

7. Larsen, J.B., M .E. Frischer, K.W. Ockelmann, L.J. Rasmussen, and B.W. Hansen (2007). Temporal occurrence of planktotrophic bivalve larvae identified morphologically and by single step nexted multiplex PCR (SSN M -PCR). J. Plankton Research. 29: 423-436.

8. S.J. Whipple, B.C. Patten, P.G. V erity, M .E. Frischer, J.D. L ong, J .C. Nejstgaard, J.T. A nderson, A. J acobsen, A. Larsen, J. M artinez-M artinez, and S. B orrett. (2007). Gaining integrated understanding of Phaeocystis spp. (Prymnesiophyceae) through model-driven laboratory and mesocosm studies. Biogeochemistry. 83: 293-309.

9. Sazhin, A.F., L.F. A rtigas, J.C. N ejstgaard, M.E. Frischer (2007). Colonization of Phaeocystis species by pinnate diatoms and other protists: A $n$ important contribution to colony biomass. Biogeochemistry. 83: 137-145.

10. Troedsson, C., M.E. Frischer, J.C. Nejstgaard, and E.M. Thompson. (2006). M olecular Quantification of Ingestion R ates and House Particle Trapping in the A ppendicularian, Oikopleura dioica. Limnology and 0 ceanography. 52: 416-427. 
11. N ejstgaard, J.C., M.E. Frischer, , P.G. V erity, J .T. A nderson, A. J acobsen, M .J . Zirbel, A. L arsen, J. M artinez, A.F. Sazhin, T. W alters, S.J. W hipple, S. B orett, B.C. Patten, J.D. L ong. (2006). Temporal patterns in planktonic food web development in mesocosms with added nutrients and Phaeocystis. M arine E cology Progress Series. 321: 99-121.

12. Frischer, M.E. and P.G. V erity. (2006). A Iternatives to Coliform B acteria As Indicators of Human Impact on Coastal E cosystems. In: Implications of L and $U$ se Change to Coastal Ecosystems Challenges to Effective Resource M anagement (eds) G.S. K leppel, M .R. DeV oe, and M. Rawson. Springer V erlag. pp. 253-273.

13. Allen, A.E., M.G. B ooth, P.G. V erity, and M .E. Frischer. (2005). Influence of nitrate availability on the distribution and abundance of heterotrophic bacterial nitrate assimilation genes in the B arents Sea during summer. A quatic M icrobial E cology. 39: 247-255.

14. Lee, R.F. and M .E. Frischer (2004). W here Have the Blue Crabs Gone: Evidence for a Drought Induced E pidemic of a Protozoan Disease. The American Scientist. 92: 547-553.

15. Nejstgaard, J.C., M.E. Frischer, C.L. Raule, T. Gruebel, K.E. K ohl berg, and P.G. V erity. (2003). A new approach to an old problem: molecular detection of algal prey in copepod guts and faecal pellets. Limnology and O ceanography: M ethods. 1: 29-38.

16. Kerkhof, L., Corredor, J., Lopez, J., Paul, J. Bronk, D., Cherrier, J. 2003. Experiment explores inter-calibration of biogeochemical flux and nucleic acid measurements. EOS 84: 167. *non-peer reviewed.

17. Allen, A.E, Howard-J ones, M.H., Booth, M.G., Frischer, M .E., V erity, P.G., Bronk, D.A., Sanderson, M .P. (2002) Importance of heterotrophic bacterial assimilation of ammonium and nitrate in the Barents Sea during summer. J ournal of M arine Systems. 38: 93-108.

18. V erity, P.G., P. W assmann, M .E. Frischer, M.H. Howard-J ones, and A.E. Allen. (2002). Grazing of primary production by microzooplankton in the Barents Sea during early summer. J ournal of M arine Systems. 38: 109-123.

19. V erity, P.G., M.R. Gilligan, M .E. Frischer, M.G. Booth, J .P. Richardson, and C. Franklin. (2002). Improving undergraduate research experiences: Lessons from a historically black university's unusual collaboration. A A HE Bulletin. 54:3-6.

20. Howard-J ones, M.H., V .D. Ballard, A.E. Allen, M .E. Frischer, and P.G. V erity. (2002). Distribution of bacterial biomass and activity in the marginal ice zone of the central $B$ arents Sea during summer. J ournal of M arine Systems. 38: 77-91.

21. Allen, A .E., M .G. B ooth, M .E. Frischer, P.G. V erity, J .P. Zehr, and S. Zani. (2001). Diversity of assimilatory nitrate reductase genes in heterotrophic bacteria and their detection in the marine environment. Appl. Environ. Microbiol. 67:5343-5348. 
22. Howard-J ones, M.H., M .E. Frischer, and P.G. Verity (2001). Determining the physiological status of individual bacteria cells. In. J.H. Paul (ed.) M ethods in microbiology volume 30: marine microbiology. Pages 175-206. A cademic Press L td, L ondon.

23. Frischer, M.E., J.M. Danforth, M .A. N ewton Healy, and F. M. Saunders. (2000). W hole cell versus total RNA extraction for the analysis of microbial community structure using 16S rR NA targeted oligonucleotide probes in saltmarsh sediments. 66:3037-3043. A ppl. Environ.

Microbiol

24. Williams, S.C., Y. Hong, D.C.A. D anavall, M.H. Howard-J ones, D. Gibson, M.E. Frischer, and P.G. V erity. (1998). Distinguishing between living and nonliving bacteria: evaluation of the vital stain propidium iodide and the combined use with molecular probes in aquatic samples. J . Microbiol. M ethods. 32:225-236.

\section{Students}

\section{Undergraduate R esearch Interns}

$\begin{array}{ll}2005-2009 & \text { LaGina Fraizer, Savannah State University } \\ 2006-2007 & \text { M eade M cGuire, R oanoke University } \\ 2006-2007 & \text { Brianna Schoen, R oanoke University } \\ 2006-2007 & \text { Dayton G ordley, R oanoke University } \\ 2006-2007 & \text { Lora Greene, R oanoke U niversity } \\ 2006 & \text { A nnette Holzle, Fachuschul M anneheim, Germany } \\ 2006 & \text { Tatjana Schneidt, Fachuschul M anneheim, Germany } \\ 2004-2005 & \text { Kenya Crawford, Savannah State University } \\ 2004-2005 & \text { Bobby Settle, Savannah State University } \\ 2004-2005 & \text { Kenya Crawford, Savannah State U niversity } \\ 2003-2005 & \text { Brian W illiams, Savannah State University } \\ 2003-2004 & \text { Robert Settel, Savannah State University } \\ 2002-2004 & \text { John Braxton, Savannah State University } \\ 2002-2003 & \text { Juan A ragon, A rmstrong A tlantic University } \\ 2000-2002 & \text { Heidi Hendrikson, Savannah State University } \\ 2000-2002 & \text { Sandra Pagen, Savannah State University } \\ 2000-2002 & \text { Christina Archer, Savannah State University } \\ 2000-2002 & \text { Tara Foy, Armstrong A tlantic State University } \\ 1999-2000 & \text { Roxanne B ower, Dalhousie University, Halifax, Canada } \\ 1998-2001 & \text { Victoria Ballard, Savannah State University } \\ 1999-2000 & \text { Barbara W ebb, Savannah State University } \\ 1999-2000 & \text { Deangelo Stuart, Savannah State University } \\ 1999-2000 & \text { Cindy Janus, Savannah State University } \\ 1999-2000 & \text { M s. Lourdes Pennill, Savannah State University }\end{array}$




\section{G raduate Students}

\section{Doctorate}

$1997-2002$

$M$ ichelle Howard-J ones. Development of the $V$ ital Stain and Probe $M$ ethod to Distinguish the Physiologic Status of Individual B acteria in the M arine Environment. (Co-advisors, P.G. V erity and T. Christina; Degree granted from Georgia Institute of Technology). Ph.D. A warded 2002.

$1998-2002$

A ndrew Allen. Distribution and Diversity of M arine Bacteria Capable of Utilizing Nitrate. (Co-advisors, P.G. V erity and D. Bronk; Degree granted from the University of Georiga). Ph.D. A warded 2002.

$2001-2008$

Paul Bradley. Cross-system comparison of nitrogen

utilization patterns in phytoplankton and heterotrophic bacteria.

(A dvisor, Deborah Bronk, V IM S). Ph.D. awarded 2008.

2004-2011

Lynn K illberg-Thoreson. Role of organic nitrogen uptake in harmful algal blooms. (A dvisor, Deborah B ronk, VIM S). Ph.D. awarded 2011.

\section{M asters Students}

$2005-2008$

$2003-2006$

$2002-2005$

$1999-2001$

$1997-2000$

1997-1999

\section{Postdoctoral Fellows}

$2002-2007$

$1998-2003$
Denis W afula, Savannah State U niversity

M egan Singl eton, Savannah State U niversity

W hitney Pal efsky, Savannah State University

Teressa Fu, Georgia Institute of Technology

$M$ ichele Healy, Georgia Institute of Technology

Nikolle Reyes, Georgia Institute of Technology

J ennifer B rofft, Ph.D. Genetic Expression of A ssimilatory Nitrate Reductase in $\mathrm{M}$ arine B acteria. Collaborative E ducation Programs with Savannah State Univeristy. Development of "Current Topics of Oceanographic" Course (Coadvisors, P.G. Verity and M.G. Gilligan)

M elissa B ooth, Ph.D. Genetic Expression of A ssimilatory Nitrate Reductase in $M$ arine Bacteria. Collaborative E ducation Programs with Savannah State Univeristy. Development of "Current Topics of Oceanographic" Course (Coadvisors, P.G. V erity and M.G. Gilligan) 